\title{
Regulation of Low Density Lipoprotein Receptor Activity in Freshly Isolated Human Lymphocytes
}

\author{
Y. K. Ho, Michael S. Brown, David W. Bilheimer, and Joseph L. Goldstein \\ From the Division of Medical Genetics, Department of Internal Medicine, University of Texas Health \\ Science Center at Dallas, Dallas, Texas 75235
}

A B S T R A C T Circulating human lymphocytes freshly isolated from venous blood of 15 normal subjects exhibited a low capacity to bind, take up, and degrade ${ }^{125}$ I-labeled low density lipoprotein (LDL). However, when these cells were incubated for $72 \mathrm{~h}$ in the absence of lipoproteins, they gradually acquired an increased number of high affinity cell surface receptors for LDL. The increase in the number of LDL receptors was associated with a 16 -fold increase in the rate at which the cells were able to take up and degrade the lipoprotein. The LDL binding and degradation processes that developed in normal lymphocytes exhibited the following characteristics: (a) high affinity (saturation was achieved at LDL concentrations below $50 \mu \mathrm{g}$ protein $/ \mathrm{ml}$ ); (b) specificity (unlabeled LDL was much more effective than human high density lipoprotein or other plasma proteins in competing with ${ }^{125}$ I-LDL for binding to the LDL receptor); and (c) feedback regulation (the increase in the number of LDL receptors that appeared after incubation of freshly isolated lymphocytes in lipoprotein-deficient medium was prevented by exposure of the cells to either LDL or a mixture of 25-hydroxycholesterol plus cholesterol but not to HDL).

Freshly isolated lymphocytes obtained from three subjects with the homozygous form of familial hypercholesterolemia failed to develop normal amounts of LDL receptor activity when incubated in medium devoid of lipoproteins. The current data indicate: (a) that the LDL receptors that appear on the surface of cholesterol-deprived, normal human lymphocytes are genetically identical to the previously char-

Dr. Ho is the recipient of a National Institutes of Health postdoctoral fellowship T 22-GM-0021. Drs. Brown and Bilheimer are Established Investigators of the American Heart Association. Dr. Goldstein is the recipient of U. S. Public Health Service Research Career Development Award GM 70, 277.

Received for publication 8 July 1976 and in revised form 16 August 1976. acterized LDL receptors of cultured human fibroblasts and long-term lymphoid cells and $(b)$ that at least one cell type in the human body, the circulating human lymphocyte, has the capacity to produce a high affinity LDL receptor that mediates the cellular uptake and degradation of plasma LDL.

\section{INTRODUCTION}

Recent studies in cultured human fibroblasts have led to the hypothesis that nonhepatic cells in the body utilize a cell surface receptor to derive cholesterol for membrane synthesis from the major cholesterolcarrying protein in human plasma, low density lipoprotein $(\mathrm{LDL})^{1}(1)$. In fibroblasts this receptor shows high affinity and specificity for LDL (2-5). Once bound to the receptor, LDL is internalized and delivered to lysosomes where both its protein and cholesteryl ester components are hydrolyzed by acid hydrolases $(3,6-8)$. The resultant free cholesterol is then able to leave the lysosome and gain access to the extralysosomal cellular compartment where it is utilized for membrane synthesis $(9,10)$. The emergence of this LDL-derived cholesterol from the lysosome regulates three events in cholesterol metabolism: $(a)$ it reduces endogenous cholesterol synthesis by suppressing the activity of 3-hydroxy-3-methylglutaryl coenzyme A reductase (HMG CoA reductase) (11); (b) it stimulates its own reesterification and storage as cholesteryl esters by activating an acyl-CoA:cholesterol acyltransferase $(12,13)$; and $(c)$ it prevents an excessive uptake of LDL-cholesterol by suppressing the synthesis of the cell surface LDL receptor (14). In addition to cultured fibroblasts, this pathway for LDL metabolism has recently been shown

\footnotetext{
${ }^{1}$ Abbreviations used in this paper: DMPA, N,N-dimethyl1,3-propanediamine; $\mathrm{FH}$, familial hypercholesterolemia, HDL, high density lipoprotein; HMG CoA reductase, 3hydroxy-3-methylglutaryl coenzyme A reductase; LDL, low density lipoprotein.
} 
TABLE I

Clinical and Biochemical Data on Patients with Homozygous Familial Hypercholesterolemia

\begin{tabular}{|c|c|c|c|c|c|c|c|}
\hline \multirow[b]{2}{*}{ Patient } & \multirow[b]{2}{*}{ Age } & \multirow[b]{2}{*}{ Sex } & \multicolumn{2}{|c|}{$\begin{array}{c}\text { Plasma } \\
\text { (holesterol* }\end{array}$} & \multirow{2}{*}{$\begin{array}{c}\text { Plasma } \\
\text { triglycerides* }\end{array}$} & \multirow{2}{*}{$\begin{array}{c}\text { Phenotype of cultured } \\
\text { fibroblasts } \$\end{array}$} & \multirow[b]{2}{*}{ Drug therapy } \\
\hline & & & Total & LDL & & & \\
\hline & & & \multicolumn{2}{|c|}{$m g / d l$} & $m g / d l$ & & \\
\hline M. C. $\S$ & 8 & $\mathrm{~F}$ & 625 & 590 & 112 & Receptor-negative & Inderal, nicotinic acid \\
\hline K. W. & 13 & $\mathrm{~F}$ & 582 & 549 & 81 & Receptor-negative & None \\
\hline D. R. & 15 & $\mathrm{~F}$ & 545 & 512 & 119 & Receptor-defective & None \\
\hline
\end{tabular}

* Measured by previously described methods (31).

‡ Determined in cultured fibroblasts by previously described criteria $(17,30)$.

$\S$ An end-to-side portacaval shunt was performed 19 mo before the current studies (31).

to be present in cultured long-term human lymphoid cells $(15,16)$.

In both fibroblasts $(2-5,17)$ and lymphoid cells (16) cultured from patients with the receptor-negative form of homozygous familial hypercholesterolemia $(\mathrm{FH})$, the cell surface LDL receptor is functionally absent. As a result, these mutant cells are unable to bind, internalize, or degrade LDL with high affinity, they cannot utilize the lipoprotein's cholesterol for membrane synthesis, and they are therefore resistant to the regulatory actions of LDL on cholesterol metabolism $(1,17)$.

The delineation of the LDL pathway in cultured fibroblasts and cultured lymphoid cells depended on the ability to induce maximal synthesis of the LDL receptor by growing the cells in the absence of an exogenous source of cholesterol so that they develop an enhanced requirement for the sterol $(1,14)$. On the other hand, when fibroblasts and lymphoid cells are exposed continuously to LDL, as when grown in the presence of whole serum, these cells establish a steady state in which they exhibit a low number of LDL receptors that is just sufficient to provide the cells with enough cholesterol to balance cellular losses that occur as a result of membrane turnover $(1,9,14)$. In general, this steady-state number of LDL receptors is less than $20 \%$ of the maximal number that the cells are capable of synthesizing after they have been deprived of cholesterol for an extended period (14). Since most cells in the body are continuously exposed to LDL and are hence never deprived of cholesterol $(18,19)$, it seems likely that in the steady state cells in the body will manifest only a small fraction of their maximal number of LDL receptors (1). Consistent with this hypothesis are the experiments of Reichl et al. who were unable to demonstrate high affinity binding, uptake, or degradation of ${ }^{125} \mathrm{I}-\mathrm{LDL}$ in lymphocytes freshly isolated from the blood of normal human subjects (20).

The studies in cultured cells predict, however, that freshly isolated lymphocytes might develop high affinity LDL receptors if the cells were incubated for a time in the absence of lipoproteins or other exogenous sources of cholesterol. The current studies were designed to test this hypothesis. The results indicate that circulating human lymphocytes obtained from normal subjects do indeed acquire high affinity LDL receptors when incubated in vitro in the absence of lipoproteins. The appearance of these receptors endows the cells with an enhanced ability to degrade LDL with high affinity. In contrast, lymphocytes isolated from FH homozygotes fail to develop significant LDL receptor activity when incubated in the absence of lipoproteins.

\section{METHODS}

Materials. ${ }^{125} \mathrm{I}$-Sodium iodide (carrier free in $0.05 \mathrm{~N}$ $\mathrm{NaOH}$ ) was purchased from Schwarz Mann Div., Becton, Dickinson and Co., Orangeburg, N. Y. RPMI 1640 medium (no. 187G), Dulbecco's phosphate-buffered saline (no. 419), and Hank's balanced salt solution (no. 402) were purchased from GIBCO, Grand Island, N. Y. Lymphoprep, a mixture of $9.6 \%$ (wt/vol) sodium metrizoate and $5.6 \%$ (wt/vol) Ficoll (final density, $1.077 \mathrm{~g} / \mathrm{ml}$ ), was obtained from GallardSchlesinger Chemical Mfg. Corp., Mineola, N. Y. Sodium heparin $(1,000 \mathrm{U} / \mathrm{ml})$ was purchased from Upjohn Co., Kalamazoo, Mich. Erythrosin B was obtained from Fisher Scientific Co., Pittsburgh, Pa. Bovine serum albumin ( $1 x$ crystallized, no. A 4378) was purchased from Sigma. 400 $\mu l$ polyethylene microfuge tubes were obtained from Beckman Instruments, Inc., Palo Alto, Calif. Tissue culture flasks and $50-\mathrm{ml}$ plastic conical culture tubes (no. 2070) were obtained from Falcon Plastics, Division of BioQuest, Oxnard, Calif. Reagents for assays were obtained from sources as previously reported $(10,11)$.

Subjects. The age and sex of each of the 15 normal subjects are given in the legends. All normal subjects were healthy individuals who had total plasma cholesterol levels of less than $220 \mathrm{mg} / \mathrm{dl}$ and who had no family history of FH. Each of the three patients with the homozygous form of $\mathrm{FH}$ had the typical clinical, genetic, and biochemical features of the disorder (21). Their clinical and biochemical data are summarized in Table I. Before obtaining blood for lymphocyte studies, informed written consent was obtained from each subject or from the parents.

Lipoproteins. Human LDL (density 1.019-1.063 g/ml), human HDL (density 1.085-1.215 g/ml), and human lipo- 
protein-deficient serum (density $>1.215 \mathrm{~g} / \mathrm{ml}$ ) were obtained from the plasma of healthy subjects and prepared by differential ultracentrifugation (11). The concentration of LDL and HDL is expressed in terms of their protein content. The mass ratio of total cholesterol to protein in LDL and HDL was $1.6: 1$ and $1: 3$, respectively. ${ }^{125}$ I-labeled LDL $(200-400 \mathrm{cpm} / \mathrm{ng}$ of protein) was prepared as previously described (2). The synthesis of cationized ${ }^{125} \mathrm{I}-\mathrm{LDL}\left({ }^{125} \mathrm{I}-\right.$ DMPA-LDL) and of cationized ${ }^{125} \mathrm{I}$-albumin ( ${ }^{125} \mathrm{I}-\mathrm{DM}$ PAalbumin) was performed as previously described with $\mathrm{N}, \mathrm{N}$ dimethyl-1,3-propanediamine (DMPA) as the tertiary amine derivative (22).

Isolation of lymphocytes. Peripheral blood lymphocytes were isolated under sterile conditions at room temperature by a modification of the method of Boyüm (23). Venous blood from each subject $(20-100 \mathrm{ml})$ was obtained after an overnight fast and was drawn into a heparin solution (100 $\mathrm{U}$ heparin $/ 10 \mathrm{ml}$ blood). The blood was immediately diluted with an equal volume of $0.15 \mathrm{M} \mathrm{NaCl}$, and each $20 \mathrm{ml}$ of the resulting blood- $\mathrm{NaCl}$ mixture was layered onto $10 \mathrm{ml}$ of Lymphoprep contained within one $50 \mathrm{ml}$ plastic conical tube. The tubes were centrifuged at $1,400 \mathrm{rpm}$ for 40 min. The interphase material containing the mononuclear cells $(6-8 \mathrm{ml} /$ tube) was collected with a Pasteur pipette, mixed with $30 \mathrm{ml}$ of Hank's balanced salt solution, and centrifuged at $1,400 \mathrm{rpm}$ for $10 \mathrm{~min}$. The resulting cell pellet from each tube was resuspended in $20 \mathrm{ml}$ of medium A (RPMI 1640 medium containing penicillin [100 U/ml] and streptomycin [100 $\mu \mathrm{g} / \mathrm{ml}]$ ) and washed by centrifugation at $1,000 \mathrm{rpm}$ for $10 \mathrm{~min}$. Each cell pellet was again resuspended in $20 \mathrm{ml}$ of medium $A$, and washed a second time. The washed cell pellets from two tubes, containing about $20-30 \times 10^{6}$ lymphocytes and representing the mononuclear cells contained in $20 \mathrm{ml}$ of venous blood, were resuspended in $12 \mathrm{ml}$ of medium A containing $10 \%$ (vol/ vol) human lipoprotein-deficient serum and placed in a 250 $\mathrm{ml}$ plastic culture flask. These stock flasks were maintained in a humidified incubator $\left(5 \% \quad \mathrm{CO}_{2}\right)$ at $37^{\circ} \mathrm{C}$. Aliquots were removed from the stock flasks either at zero time or after incubation for the indicated intervals and used for the assays described below.

Cell viability, as assessed by erythrosin B exclusion, was routinely determined for each lymphocyte preparation and was always greater than $90 \%$ both before and after incubation for $72 \mathrm{~h}$ in both the normal and $\mathrm{FH}$ homozygote cells. Purity of the cell preparations was assessed after staining smears with Wright-Giemsa. Differential counts revealed that $90-95 \%$ of the cells that had been incubated for $72 \mathrm{~h}$ were morphologically identifiable as lymphocytes. Only an occasional platelet was seen on examination of the smears.

Binding of ${ }^{125} \mathrm{I}-L D L$ by intact lymphocytes at $4^{\circ} \mathrm{C}$. Lymphocytes from the stock flasks were harvested by centrifugation $\left(1,200 \mathrm{rpm}, 10 \mathrm{~min}, 4^{\circ} \mathrm{C}\right)$, washed once in $6 \mathrm{ml}$ of buffer B (Dulbecco's phosphate-buffered saline containing $50 \mu \mathrm{M} \mathrm{CaCl}{ }_{2}$ and $20 \mathrm{mg} / \mathrm{ml}$ bovine serum albumin), and resuspended in ice-cold buffer $B$ at a final concentration of about $50 \times 10^{6}$ cells $/ \mathrm{ml}$. Aliquots of this cell suspension (75 $\mu \mathrm{l}$ containing about $4 \times 10^{6}$ cells and $160-280 \mu \mathrm{g}$ total cell protein) were placed in a $400 \mu$ l polyethylene microfuge tube in a final volume of $100 \mu \mathrm{l}$ of buffer $B$. The indicated concentration of freshly filtered ${ }^{125}$ I-LDL (16) was added in the presence or absence of excess unlabeled $\mathrm{LDL}$, and the cells were incubated for $30 \mathrm{~min}$ at $4^{\circ} \mathrm{C}$, after which the cells were collected by centrifugation, washed as previously described for cultured human longterm lymphoid cells, and the total amount of ${ }^{125}$ I-LDL bound to the cells was determined (16). All of the above additions and centrifugations were carried out in a $4^{\circ} \mathrm{C}$ cold room. Total binding of ${ }^{125} \mathrm{I}-\mathrm{LDL}$ represents the amount of ${ }^{125} \mathrm{I}$ LDL bound to the cells in the absence of excess unlabeled LDL. High affinity binding is that component of the total that was inhibited competitively by the presence of an excess of unlabeled LDL.

Cellular accumulation and proteolytic degradation of ${ }^{125}$ I$L D L$ by intact lymphocytes at $37^{\circ} \mathrm{C}$. Aliquots of lymphocytes from the stock flasks $(2 \mathrm{ml}$ of medium containing about $4 \times 10^{6}$ cells) were transferred to 30 -ml flasks. ${ }^{125} \mathrm{I}-$ LDL was added in the presence or absence of excess unlabeled LDL and the cells were incubated at $37^{\circ} \mathrm{C}$ for the indicated interval, after which the cells and medium were separated by centrifugation $\left(1700 \mathrm{rpm}, 5 \mathrm{~min}, 4^{\circ} \mathrm{C}\right)$. The medium was then treated with trichloroacetic acid to a final concentration of $10 \%$ ( $\mathrm{vol} / \mathrm{vol})$, after which the precipitate was removed by centrifugation and the supernate was treated with hydrogen peroxide and extracted with chloroform to remove free iodine (24). An aliquot of the aqueous phase was counted to determine the amount of ${ }^{125} \mathrm{I}$-labeled acid-soluble material formed by the cells and released to the medium (3). Degradation activity is expressed as nanograms of ${ }^{125}$ I-LDL protein degraded to acid-soluble material per milligram of cell protein. A blank value due to the presence of small amounts of acid-soluble material $(<0.1 \%$ of total added radioactivity) in the ${ }^{125} \mathrm{I}-\mathrm{LDL}$ preparation was routinely determined at the appropriate concentration of the lipoprotein by incubation at $37^{\circ} \mathrm{C}$ in medium containing no cells $(3,16)$. Total degradation of ${ }^{125}$ I-LDL represents the amount of ${ }^{125}$ I-LDL degraded in the absence of excess unlabeled LDL. High affinity degradation is that component of the total that was inhibited competitively by the presence of an excess of unlabeled LDL. The total cellular content of ${ }^{125} \mathrm{I}-\mathrm{LDL}$ (i.e., the ${ }^{125} \mathrm{I}-\mathrm{LDL}$ contained both at the receptor site on the cell surface and within the cell) was determined from the cell pellet with the washing procedure previously described for cultured human long-term lymphoid cells (16). The cellular content of ${ }^{125} \mathrm{I}-\mathrm{LDL}$ is expressed as the nanograms of ${ }^{125} \mathrm{I}-\mathrm{LDL}$ protein bound to the cell per milligram of total cell protein.

Other assay. The content of protein was determined by a modification of the method of Lowry et al. (25), by using bovine serum albumin as a standard.

\section{RESULTS}

To assay for high affinity cell surface LDL binding activity in human lymphocytes, the cells were incubated at $4^{\circ} \mathrm{C}$ with low concentrations of ${ }^{125} \mathrm{I}-\mathrm{LDL}$ either in the absence or presence of a 25 -fold excess of unlabeled LDL. The amount of ${ }^{125} \mathrm{I}-\mathrm{LDL}$ bound to the cell membrane was then measured by using a washing technique that was previously developed for assay of ${ }^{125} \mathrm{I}-\mathrm{LDL}$ binding in human lymphoid cells maintained in long-term culture (16). In this type of competition assay, the high affinity binding is defined as the amount of ${ }^{125}$ I-LDL that is prevented from binding to the cell membrane by the excess of unlabeled LDL (i.e., the difference between the ${ }^{125}$ I-LDL binding obtained in the absence and presence of unlabeled LDL). When freshly isolated human lymphocytes obtained from a normal subject were incubated with ${ }^{125} \mathrm{I}-\mathrm{LDL}$ at $4^{\circ} \mathrm{C}$, relatively little high affinity binding was observed (Fig. 1, zero time). 


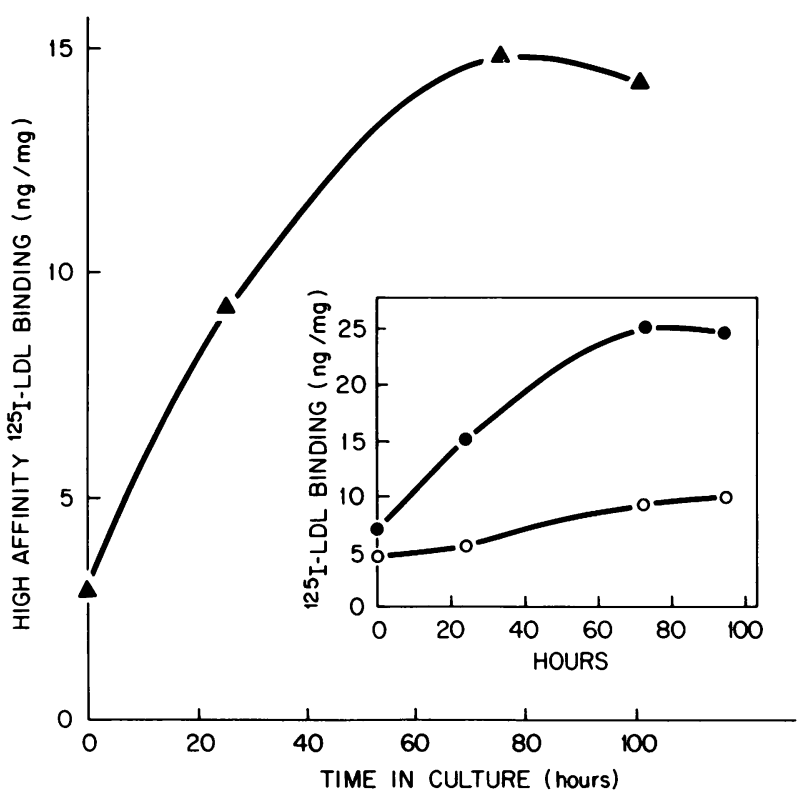

FIGURE 1 Increase in high affinity binding activity for ${ }^{125}$ I-LDL in normal lymphocytes during incubation in the absence of lipoproteins. Lymphocytes were isolated from 80 $\mathrm{ml}$ of venous blood obtained from a healthy $24 \mathrm{yr}$-old male (T.B.), and four replicate stock flasks were prepared as described in Methods. The cells were incubated at $37^{\circ} \mathrm{C}$ in medium $\mathrm{A}$ containing $10 \%$ lipoprotein-deficient serum. After the indicated interval, the lymphocytes from one stock flask were harvested, washed, and resuspended in ice-cold buffer B for assay of ${ }^{125} \mathrm{I}-\mathrm{LDL}$ binding as described in Methods. Each binding assay was conducted in $100 \mu \mathrm{l}$ of buffer B containing about $4 \times 10^{6}$ intact cells (160-220 $\mu \mathrm{g}$ of total cell protein), $10 \mu \mathrm{g}$ protein/ml of ${ }^{125} \mathrm{I}-\mathrm{LDL}$ (188 $\mathrm{cpm} / \mathrm{ng}$ ) either in the presence $(O)$ or absence (O) of 250 $\mu \mathrm{g}$ protein $/ \mathrm{ml}$ of unlabeled LDL. The cells were incubated at $4^{\circ} \mathrm{C}$ for $30 \mathrm{~min}$, after which the total amount of ${ }^{125} \mathrm{I}-\mathrm{LDL}$ bound to the cells $(0,0)$ was determined as described under Methods. Each value represents the mean of triplicate assays. The values for high affinity ${ }^{125}$ I-LDL binding $(\Delta)$ represent the difference between the values for ${ }^{125}$ I-LDL bound in the absence $(O)$ and presence $(O)$ of unlabeled LDL.

However, incubation of such lymphocytes at $37^{\circ} \mathrm{C}$ in tissue culture medium deficient in lipoproteins led to a progressive increase in their ability to bind ${ }^{125}$ I-LDL as determined by repeated binding assays over a $96-\mathrm{h}$ interval. An identical pattern of appearance of high affinity ${ }^{125}$ I-LDL binding activity was obtained when the experiment in Fig. 1 was repeated by using lymphocytes isolated from a different normal subject (E.S., a 29-yr-old female). During the 96-h incubation, the number of lymphocytes in each flask remained constant, and there was no change in the morphologic appearance of the cells.

Fig. 2 shows that the high affinity binding activity that developed in normal lymphocytes after incubation for $72 \mathrm{~h}$ in medium devoid of lipoprotein was relatively specific for LDL. Thus, when pre- incubated lymphocytes were incubated with ${ }^{125} \mathrm{I}-\mathrm{LDL}$ at a concentration of $15 \mu \mathrm{g}$ protein $/ \mathrm{ml}$ at $4^{\circ} \mathrm{C}$ in the presence of increasing concentrations of unlabeled LDL, a $50 \%$ reduction in the binding of ${ }^{125} \mathrm{I}-\mathrm{LDL}$ occurred at a concentration of $15 \mu \mathrm{g}$ protein $/ \mathrm{ml}$ of unlabeled LDL. On the other hand, HDL was much less effective in competitively inhibiting the binding of ${ }^{125} \mathrm{I}-\mathrm{LDL}$ to the lymphocyte membrane, $50 \%$ inhibition requiring a concentration of more than 240 $\mu \mathrm{g}$ protein $/ \mathrm{ml}$ of HDL. Further evidence for the specificity of the LDL binding was the fact that ${ }^{125} \mathrm{I}$ LDL binding occurred when the lipoprotein was present at only $15 \mu \mathrm{g}$ protein $/ \mathrm{ml}$ even though a 15,000 fold molar excess of bovine serum albumin $(20 \mathrm{mg} / \mathrm{ml})$ was present in the incubation medium.

Previous studies have demonstrated that binding of LDL to its high affinity receptor in cultured human fibroblasts $(3,4)$ and in cultured human lymphoid cells (16) leads to internalization and degradation of the lipoprotein. Fig. 3 shows that freshly isolated lymphocytes obtained from a normal subject, which exhibited a relatively low number of high affinity LDL binding sites (Fig. 1, zero time), also exhibited a relatively low ability to degrade ${ }^{125}$ I-LDL. How-

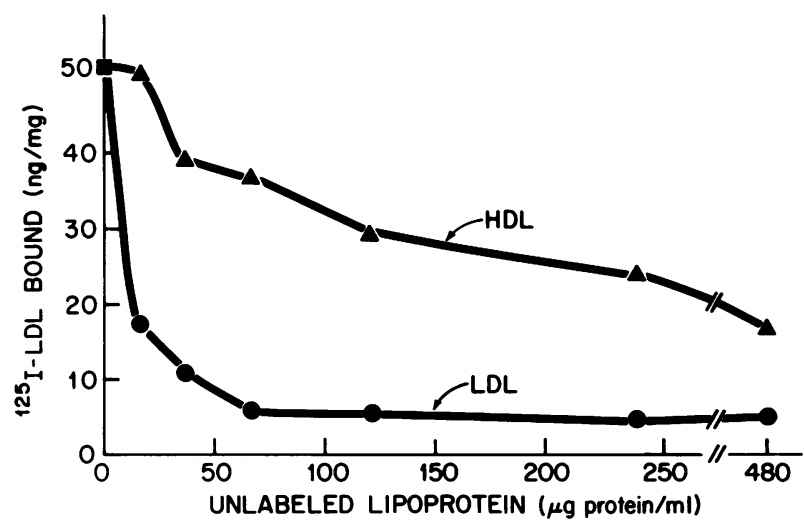

Figure 2 Effect of unlabeled plasma lipoproteins on the binding of ${ }^{125} \mathrm{I}-\mathrm{LDL}$ to normal lymphocytes at $4^{\circ} \mathrm{C}$. Lymphocytes were isolated from $60 \mathrm{ml}$ of venous blood obtained from a healthy 25 yr-old male (V.C.), and replicate stock flasks were prepared as described in Methods. The cells were incubated for $72 \mathrm{~h}$ at $37^{\circ} \mathrm{C}$ in medium $\mathrm{A}$ containing $10 \%$ lipoprotein-deficient serum, after which the cells from all the flasks were combined and the lymphocytes were harvested, washed, and resuspended in ice-cold buffer $B$ for assay of ${ }^{125}$ I-LDL binding as described in Methods. Each binding assay was conducted in $100 \mu$ l of buffer $B$ containing about $4 \times 10^{6}$ intact cells $(200-220 \mu \mathrm{g}$ of total cell protein), $15 \mu \mathrm{g}$ protein $/ \mathrm{ml}$ of ${ }^{125} \mathrm{I}-\mathrm{LDL}(163 \mathrm{cpm} / \mathrm{ng})$, and the indicated concentration of either unlabeled HDL $(\Delta)$ or unlabeled LDL (O). The cells were incubated at $4^{\circ} \mathrm{C}$ for $30 \mathrm{~min}$, after which the total amount of ${ }^{125}$ I-LDL bound to the cells was determined as described in Methods. The value for ${ }^{125}$ I-LDL binding when no unlabeled lipoprotein was added $(\square)$ represents the mean of triplicate assays. All other values represent single assays. 
ever, during incubation at $37^{\circ} \mathrm{C}$ for $72 \mathrm{~h}$ in medium devoid of lipoproteins, when the cells were acquiring increased high affinity LDL binding activity (Fig. 1), they also were acquiring an increased ability to degrade ${ }^{125}$ I-LDL (Fig. 3).

Fig. 4 shows the time course of metabolism of ${ }^{125} \mathrm{I}-\mathrm{LDL}$ at $37^{\circ} \mathrm{C}$ by the high affinity process in normal lymphocytes that had been incubated for $72 \mathrm{~h}$ in medium devoid of lipoproteins. As previously observed for cultured human fibroblasts $(3,4)$ and cultured human lymphoid cells (16), the cellular content of ${ }^{125}$ I-LDL rose and reached a steady-state plateau at about $2 \mathrm{~h}$ (Fig. 4A), while the rate of degradation of ${ }^{125} \mathrm{I}-\mathrm{LDL}$ continued in a nearly linear fashion for $8 \mathrm{~h}$ (Fig. 4B). In the presence of excess unlabeled LDL, both the uptake of ${ }^{125} \mathrm{I}-\mathrm{LDL}$ and its rate of degradation were reduced proportionately.

The saturation curve for ${ }^{125}$ I-LDL degradation is shown in Fig. 5. As previously observed in cultured fibroblasts $(3,7)$, the LDL concentration curve in normal lymphocytes consisted of two components, a high affinity component that reached saturation at an LDL concentration of about $50 \mu \mathrm{g}$ protein $/ \mathrm{ml}$ and

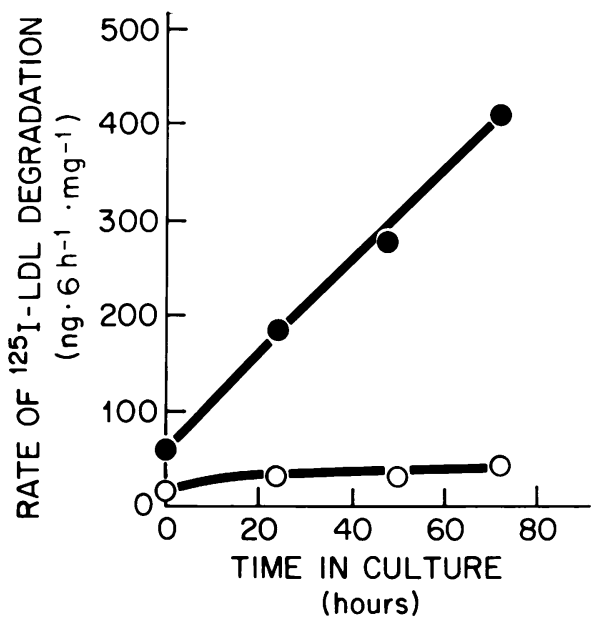

FIGURE 3 Increase in the ability of normal lymphocytes to degrade ${ }^{125}$ I-LDL after incubation in the absence of lipoproteins. Lymphocytes were isolated from $80 \mathrm{ml}$ of venous blood obtained from a healthy 32 yr-old female (V. J.), and four replicate stock flasks were prepared as described in Methods. The cells were incubated at $37^{\circ} \mathrm{C}$ in medium A containing $10 \%$ lipoprotein-deficient serum. At each indicated interval, the cells and medium from one flask were divided into six 2-ml aliquots. Each $2 \mathrm{ml}$ aliquot was transferred to a $30-\mathrm{ml}$ flask, after which was added $10 \mu \mathrm{g}$ protein $/ \mathrm{ml}$ of ${ }^{125} \mathrm{I}-\mathrm{LDL}(265 \mathrm{cpm} / \mathrm{ng})$ either in the presence (O) or absence (O) of $250 \mu \mathrm{g}$ protein $/ \mathrm{ml}$ of unlabeled LDL. The flasks were incubated at $37^{\circ} \mathrm{C}$ for $6 \mathrm{~h}$, after which the cells were removed by centrifugation and the content of ${ }^{125}$ I-labeled acid-soluble material in the medium was determined as described under Methods. The content of cellular protein in each flask averaged $160 \mu \mathrm{g}$. Each value represents the mean of triplicate incubations.

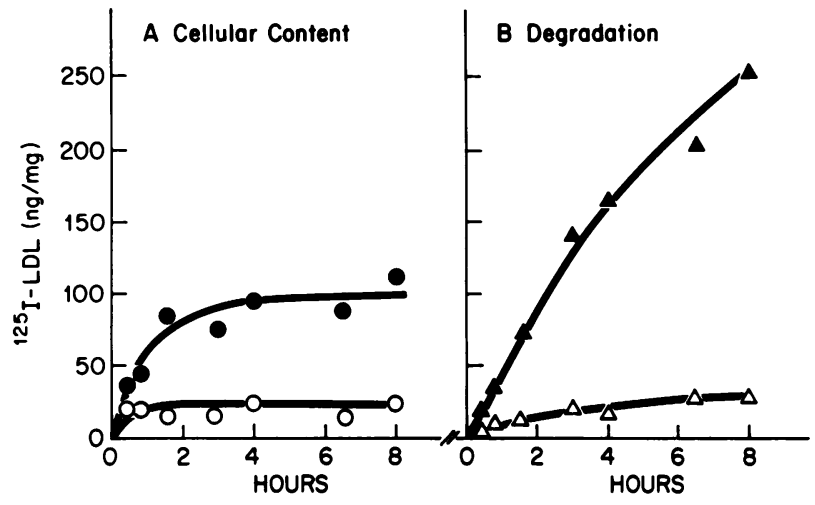

Figure 4 Time course of metabolism of ${ }^{125} \mathrm{I}-\mathrm{LDL}$ at $37^{\circ} \mathrm{C}$ in normal lymphocytes subjected to prior incubation in the absence of lipoproteins. Lymphocytes were isolated from 100 $\mathrm{ml}$ of venous blood obtained from a healthy $25 \mathrm{yr}$-old male (J. L.), and replicate stock flasks were prepared as described in Methods. After the cells had incubated at $37^{\circ} \mathrm{C}$ for $72 \mathrm{~h}$ in medium A containing $10 \%$ lipoprotein-deficient serum, the cells from all of the flasks were combined and divided into $212-\mathrm{ml}$ aliquots. Each $2 \mathrm{ml}$ aliquot was transferred to a $30-\mathrm{ml}$ flask, after which was added $10 \mu \mathrm{g}$ protein/ml of ${ }^{125} \mathrm{I}-\mathrm{LDL}(189 \mathrm{cpm} / \mathrm{ng})$ either in the presence $(O, \triangle)$ or absence $(\boldsymbol{O}, \Delta)$ of $250 \mu \mathrm{g}$ protein $/ \mathrm{ml}$ of unlabeled LDL. After incubation at $37^{\circ} \mathrm{C}$ for the indicated time, the medium and cells from each flask were separated by centrifugation, after which the content of ${ }^{125}$ I-labeled acid-soluble material in the medium $(\Delta, \Delta)$ and the cellular content of ${ }^{125} \mathrm{I}-\mathrm{LDL}(0, \mathrm{O})$ were determined as described under Methods. The content of cellular protein in each flask averaged $280 \mu \mathrm{g}$. Each value for the closed symbols $(\boldsymbol{O}, \mathbf{\Delta})$ represents the average of duplicate incubations. Each value for the open symbols $(O, \Delta)$ represent single incubations.

an apparently nonsaturable component that caused the rate of degradation to increase slightly in a linear fashion at LDL concentrations above $50 \mu \mathrm{g}$ protein/ $\mathrm{ml}$. As with high affinity ${ }^{125} \mathrm{I}-\mathrm{LDL}$ binding at $4^{\circ} \mathrm{C}$ (Fig. 2), the rate of degradation of ${ }^{125} \mathrm{I}-\mathrm{LDL}$ at $37^{\circ} \mathrm{C}$ was competitively inhibited by LDL, whereas HDL was much less effective (Fig. 6).

Considered together, the data in Figs. 1-6 suggest that circulating normal lymphocytes incubated in the absence of lipoproteins acquire an increased number of specific, high affinity LDL receptors and that these receptors facilitate the uptake and degradation of LDL in a manner similar to that previously observed in cultured human fibroblasts and cultured human lymphoid cells. In human fibroblasts the induction of LDL receptors has been shown to be a consequence of the removal of the cells from an exogenous source of cellular cholesterol (14). That a similar mechanism was also responsible for the induction of LDL receptors in circulating lymphocytes is indicated by the data in Table II. Inclusion of LDL in the medium during the 72 -h incubation prevented the induction of the enhanced receptor-mediated degradation of ${ }^{125}$ I-LDL (exp. A and B). This induction was also 


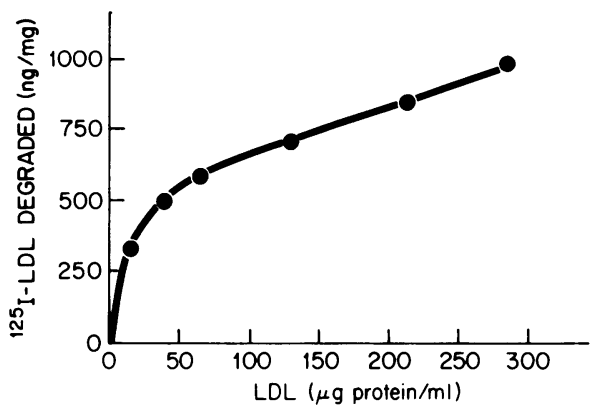

FIGURE 5 Rate of degradation of ${ }^{125}$ I-LDL in normal lymphocytes as a function of the ${ }^{125} \mathrm{I}-\mathrm{LDL}$ concentration. Lymphocytes were isolated from $40 \mathrm{ml}$ of venous blood obtained from a healthy 27 yr-old male (F.C.), and replicate stock flasks were prepared as described in Methods. After the cells had incubated for $72 \mathrm{~h}$ in medium A containing $10 \%$ lipoprotein-deficient serum, the cells from all of the flasks were combined and divided into 12 2-ml aliquots. Each $2 \mathrm{ml}$ aliquot was transferred to a $30-\mathrm{ml}$ flask, after which was added the indicated concentration of ${ }^{125} \mathrm{I}-\mathrm{LDL}(392 \mathrm{cpm} /$ ng). After incubation at $37^{\circ} \mathrm{C}$ for $6 \mathrm{~h}$, the cells were removed from each flask by centrifugation, after which the content of ${ }^{125}$ I-labeled acid-soluble material in the medium was determined as described under Methods. The content of cellular protein in each flask averaged $180 \mu \mathrm{g}$. Each value represents the average of duplicate incubations.

prevented by inclusion in the medium of a mixture of 25-hydroxycholesterol and cholesterol (exp. A), a mixture that prevents the induction of LDL receptor activity in human fibroblasts (14). On the other hand, incubation of lymphocytes with HDL at a protein concentration of $100 \mu \mathrm{g} / \mathrm{ml}$ did not prevent the induction of LDL receptor activity (exp. B).

To test the specificity of the effect of LDL and the mixture of sterols in preventing the enhancement of the receptor-mediated degradation of ${ }^{125} \mathrm{I}-\mathrm{LDL}$, the ability of the incubated lymphocytes to degrade ${ }^{125} \mathrm{I}$ DMPA-albumin was examined. We have previously shown that in fibroblasts ${ }^{125}$ I-DMPA-albumin, which has a strong positive charge, binds avidly to negatively-charged sites on the cell surface and is then taken up by cells and degraded in lysosomes (22). Thus, ${ }^{125}$ I-DMPA-albumin serves as a good marker for the overall rate of cellular endocytosis and lysosomal proteolysis. $^{2}$ As shown in Table II, neither LDL itself nor the mixture of 25-hydroxycholesterol and cholesterol suppressed the degradation of ${ }^{125}$ I-DMPAalbumin in incubated lymphocytes under conditions in which the degradation of ${ }^{125}$ I-LDL was reduced by more than 10 -fold.

In other experiments not shown, normal lymphocytes that had been incubated for $72 \mathrm{~h}$ in the absence of lipoproteins degraded ${ }^{125} \mathrm{I}-\mathrm{LDL}$ at a rate that was sixfold faster than that observed in freshly isolated, unin-

\footnotetext{
${ }^{2}$ Basu, S. K., R. G. W. Anderson, J. L. Goldstein, and M. S.
} Brown. 1976. Manuscript to be submitted for publication. cubated cells. In the same cells, however, there was no increase in the rate of degradation of ${ }^{125}$ I-DMPALDL, a macromolecule that, like ${ }^{125}$ I-DMPA-albumin, gains entry to cellular lysosomes by binding nonspecifically to negatively-charged sites on the cell surface rather than by binding to the LDL receptor $(22) .^{2}$

To determine whether the LDL receptor that appeared in freshly isolated lymphocytes was genetically the same as the LDL receptor previously characterized in cultured fibroblasts and long-term lymphoid cells, we compared the appearance of LDL receptor activity in cells from normal subjects and from patients with the homozygous form of FH. Table III shows that at zero time the total amount of ${ }^{125}$ I-LDL binding at $4^{\circ} \mathrm{C}$ in lymphocytes from four normal subjects was low and there was little to no competition when an excess of unlabeled LDL was present, indicating that very little, if any, of the observed binding was due to the high affinity LDL receptor. In contrast, when normal lymphocytes were incubated for $72 \mathrm{~h}$ in the absence of lipoproteins and then incubated with ${ }^{125} \mathrm{I}-\mathrm{LDL}$ at $10 \mu \mathrm{g}$ protein $/ \mathrm{ml}$, the mean

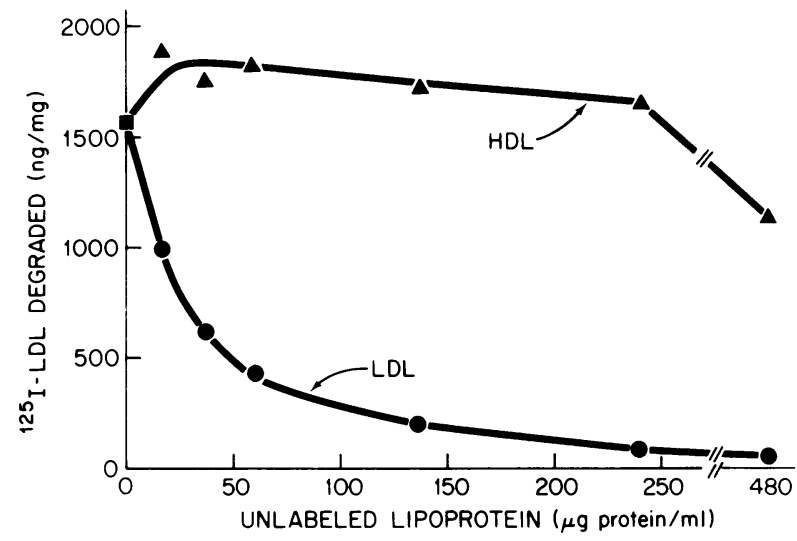

FIGURE 6 Effect of unlabled plasma lipoproteins on the degradation of ${ }^{125}$ I-LDL in normal lymphocytes. Lymphocytes were isolated from $40 \mathrm{ml}$ of venous blood obtained from a healthy 25 yr-old male (V. C.), and two replicate stock flasks were prepared as described in Methods. After the cells had incubated for $72 \mathrm{~h}$ at $37^{\circ} \mathrm{C}$ in medium A containing $10 \%$ lipoprotein-deficient serum, the medium and cells from the two flasks were combined in a final volume of $34 \mathrm{ml}$ of medium A containing $10 \%$ human lipoprotein-deficient serum. The resulting mixture was then divided into 17 2 -ml aliquots. Each $2 \mathrm{ml}$ aliquot was transferred to a 30 ml flask, after which was added $15 \mu \mathrm{g}$ protein $/ \mathrm{ml}$ of ${ }^{125} \mathrm{I}$ LDL $(218 \mathrm{cpm} / \mathrm{ng})$ and the indicated concentration of either unlabeled HDL $(\boldsymbol{\Delta})$ or unlabeled LDL $(\bullet)$. After incubation for $6 \mathrm{~h}$ at $37^{\circ} \mathrm{C}$, the cells from each flask were removed by centrifugation, and the content of ${ }^{125}$ I-labeled acidsoluble material in the medium was determined as described under Methods. The content of cellular protein in each flask averaged $110 \mu \mathrm{g}$. The value for ${ }^{125} \mathrm{I}-\mathrm{LDL}$ degradation when no unlabeled lipoprotein was added $(\boldsymbol{\square})$ represents the mean of triplicate incubations. All other values represent single incubations. 
TABLE II

Prevention of the Appearance of Enhanced ReceptorMediated Degradation of ${ }^{125}$ I-LDL in Normal

Lymphocytes by Inclusion of LDL or

Sterols in the Prior Incubation

Medium

\begin{tabular}{|c|c|c|c|}
\hline \multirow[b]{2}{*}{ Prior treatment of cells } & \multicolumn{2}{|c|}{${ }^{125}$ I-LDL degraded } & \multirow{2}{*}{$\begin{array}{l}\text { 125I-DMPA- } \\
\text { albumin } \\
\text { degraded }\end{array}$} \\
\hline & Total & $\begin{array}{l}\text { High } \\
\text { affinity }\end{array}$ & \\
\hline & \multicolumn{2}{|c|}{$\begin{array}{c}n g \cdot 6 h^{-1} \\
\text { mg protein }\end{array}$} & $\begin{array}{l}n g \cdot 6 h^{-1} \\
\cdot m g \text { protein }\end{array}$ \\
\hline Exp.A & & & \\
\hline LPDS* & 506 & 498 & 4,540 \\
\hline LPDS + LDL & 6.0 & 4.9 & 3,900 \\
\hline $\begin{array}{l}\text { LPDS + 25-Hydroxy- } \\
\text { cholesterol + Cholesterol } \\
\text { Exp. B }\end{array}$ & 2.0 & 0.9 & 4,450 \\
\hline LPDS $^{*}$ & 505 & 465 & 4,940 \\
\hline LPDS + LDL & 35 & 34 & 5,760 \\
\hline LPDS + HDL & 1,025 & 979 & 4,270 \\
\hline
\end{tabular}

Lymphocytes were isolated from $100 \mathrm{ml}$ of venous blood obtained from a healthy 27-yr-old male (F. C.) and from a healthy 23-yr-old female (J. F.) for Exp. A and B, respectively. For each experiment, three replicate stock flasks were prepared as described in Methods except that each stock flask received cells isolated from $33 \mathrm{ml}$ of venous blood. Each stock flask contained $12 \mathrm{ml}$ of medium A containing $10 \%$ lipoprotein-deficient serum plus one of the indicated additions (Exp. A: none, $100 \mu \mathrm{g}$ protein $/ \mathrm{ml}$ of unlabeled LDL, or $1 \mu \mathrm{g} / \mathrm{ml}$ of 25-hydroxycholesterol plus $16 \mu \mathrm{g} / \mathrm{ml}$ of cholesterol added in $35 \mu \mathrm{l}$ of ethanol; Exp. B: none, $50 \mu \mathrm{g}$ protein $/ \mathrm{ml}$ of unlabeled LDL, or $100 \mu \mathrm{g}$ protein $/ \mathrm{ml}$ of unlabeled HDL). After incubation at $37^{\circ} \mathrm{C}$ for $72 \mathrm{~h}$, the cells from each flask were harvested by centrifugation $(1,000 \mathrm{rpm}$, $10 \mathrm{~min}, 24^{\circ} \mathrm{C}$ ), washed in $15 \mathrm{ml}$ of medium A containing $10 \%$ human lipoprotein-deficient serum, and recentrifuged. Each cell pellet was then resuspended in $12.5 \mathrm{ml}$ of medium A containing $10 \%$ human lipoprotein-deficient serum and the resulting suspension of cells was equally divided into six 2-ml aliquots. Each $2 \mathrm{ml}$ aliquot was transferred to a 30 -ml flask, after which was added either $7.3 \mu \mathrm{g} / \mathrm{ml}$ of ${ }^{125 I-D M P A-a l b u m i n ~(E x p . ~ A, ~} 664 \mathrm{cpm} / \mathrm{ng}$; Exp. B, 559 $\mathrm{cpm} / \mathrm{ng}$ ) or $10 \mu \mathrm{g}$ protein/ml of ${ }^{125} \mathrm{I}-\mathrm{LDL}$ (Exp. A, 369 $\mathrm{cpm} / \mathrm{ng}$; Exp. B, $178 \mathrm{cpm} / \mathrm{ng}$ ) in the presence or absence of $250 \mu \mathrm{g}$ protein $/ \mathrm{ml}$ of unlabeled LDL. After incubation at $37^{\circ} \mathrm{C}$ for $6 \mathrm{~h}$, the medium and cells from each flask were separated, after which the content of ${ }^{125}$ I-labeled acid-soluble material in the medium was determined as described under Methods. Total and high affinity degradation of ${ }^{125}$ I-LDL were determined as described under Methods. The content of cellular protein averaged $180 \mu \mathrm{g} /$ flask (Exp. A) and 120 $\mu \mathrm{g} /$ flask (Exp. B). Each value represents the average of duplicate incubations.

${ }^{*}$ LPDS, lipoprotein-deficient serum.

total binding had risen to $20 \mathrm{ng} / \mathrm{mg}$ protein. Of this amount, a mean of $14 \mathrm{ng} / \mathrm{mg}$ was excluded from the cell surface when the binding assay was carried out in the presence of $250 \mu \mathrm{g}$ protein/ml of unlabeled
TABLE III

${ }^{125}$ I-LDL Binding at $4^{\circ} \mathrm{C}$ in Freshly Isolated Lymphocytes and in Lymphocytes that Had Undergone Prior Incubation in the Absence of Lipoproteins

\begin{tabular}{|c|c|c|c|c|}
\hline \multirow{2}{*}{$\begin{array}{l}\text { Subject providing } \\
\text { cells }\end{array}$} & \multirow{2}{*}{$\begin{array}{l}\text { Duration of prior } \\
\text { incubation in } \\
\text { absence of } \\
\text { lipoproteins }\end{array}$} & \multicolumn{3}{|c|}{${ }^{125}$ I-LDL Binding } \\
\hline & & \multicolumn{2}{|c|}{ Total } & High affinity \\
\hline & $h$ & \multicolumn{3}{|c|}{$n g / m g$ protein } \\
\hline \multicolumn{5}{|l|}{ Normal subjects } \\
\hline J. W. (12 M) & 0 & & 3.7 & 0.2 \\
\hline T. B. $(24 \mathrm{M})$ & 0 & & 4.6 & 0.0 \\
\hline V. C. $(25 \mathrm{M})$ & 0 & & 5.3 & 1.7 \\
\hline \multirow[t]{2}{*}{ J. L. $(25 \mathrm{M})$} & 0 & & 7.7 & 0.0 \\
\hline & & Mean & 5.3 & 0.5 \\
\hline D. C. $(11 \mathrm{M})$ & 72 & & 13 & 10 \\
\hline M. S. (24 F) & 72 & & 34 & 24 \\
\hline M. E. $(30 \mathrm{~F})$ & 72 & & 21 & 18 \\
\hline F. C. $(27 \mathrm{M})$ & 72 & & 21 & 10 \\
\hline D. B. $(35 \mathrm{M})$ & 72 & & 13 & 10 \\
\hline & & Mean & 20 & 14 \\
\hline \multicolumn{5}{|c|}{ FH Homozygotes } \\
\hline M.C. $(8 \mathrm{~F})$ & 72 & & 3.0 & 0.9 \\
\hline \multirow[t]{2}{*}{ D. R. $(15 \mathrm{~F})$} & 72 & & 4.8 & 1.0 \\
\hline & & Mean & 3.9 & 1.0 \\
\hline
\end{tabular}

Lymphocytes were isolated from $20 \mathrm{ml}$ of venous blood obtained from each of the indicated subjects, and a single stock flask was prepared as described in Methods. After incubation at $37^{\circ} \mathrm{C}$ in medium A containing $10 \%$ lipoproteindeficient serum for the indicated time, the lymphocytes were harvested, washed, and resu spended in ice-cold buffer $B$ as described in Methods. Each binding assay was conducted in $100 \mu \mathrm{l}$ of buffer B containing 3-4 $\times 10^{6}$ intact cells (160-280 $\mu \mathrm{g}$ of total cell protein) and $10 \mu \mathrm{g}$ protein $/ \mathrm{ml}$ of ${ }^{125} \mathrm{I}-\mathrm{LDL}$ $(200-223 \mathrm{cpm} / \mathrm{ng})$ either in the presence or absence of 250 $\mu \mathrm{g}$ protein $/ \mathrm{ml}$ of unlabeled LDL. The cells were incubated at $4^{\circ} \mathrm{C}$ for $30 \mathrm{~min}$, after which the total amount of ${ }^{125}$ I-LDL bound to the cells was determined as described in Methods. Total and high affinity binding of ${ }^{125}$ I-LDL were determined as described under Methods. Each value represents the mean of triplicate (- unlabeled LDL) or duplicate (+ unlabeled LDL) assays.

LDL and thus represented binding to the high affinity saturable LDL receptor site. In cells from two FH homozygotes incubated for $72 \mathrm{~h}$ in the absence of lipoproteins, the high affinity component of the total ${ }^{125} \mathrm{I}-\mathrm{LDL}$ binding was $1.0 \mathrm{ng} / \mathrm{mg}$. This $93 \%$ reduction in high affinity LDL binding activity at $4^{\circ} \mathrm{C}$ in the lymphocytes of $\mathrm{FH}$ homozygotes was associated with a $96 \%$ reduction in the rate of high affinity degradation of ${ }^{125} \mathrm{I}-\mathrm{LDL}$ at $37^{\circ} \mathrm{C}$ when the cells from three FH homozygotes were compared with those from seven normal subjects after incubation for $72 \mathrm{~h}$ in the absence of lipoproteins (Table IV).

LDL Receptors in Circulating Lymphocytes 
TABLE IV

Degradation of ${ }^{125 I-L D L}$ at $37^{\circ} \mathrm{C}$ in Freshly Isolated Lymphocytes and in Lymphocytes That Had Undergone Prior Incubation in the Absence of Lipoproteins

\begin{tabular}{ccc}
\hline & $\begin{array}{c}\text { Duration of prior } \\
\text { incubation in } \\
\text { absence of } \\
\text { lipoproteins } \\
\text { cells }\end{array}$ & ${ }^{125}$ I-LDL Degraded \\
\hline$h$ & Total & High affinity \\
\hline
\end{tabular}

Normal subjects

\begin{tabular}{|c|c|c|c|c|}
\hline J. W. (12 M) & 0 & & 40 & 34 \\
\hline T. B. $(24 \mathrm{M})$ & 0 & & 36 & 35 \\
\hline \multirow[t]{2}{*}{ V. C. $(25 \mathrm{M})$} & 0 & & 56 & 52 \\
\hline & & Mean & 44 & 40 \\
\hline D. C. $(11 \mathrm{M})$ & 72 & & 403 & \\
\hline J. W. (12 M) & 72 & & 496 & 460 \\
\hline M. S. (24 F) & 72 & & 1295 & 1203 \\
\hline M. E. $(30 \mathrm{~F})$ & 72 & & 678 & 613 \\
\hline F. C. $(27 \mathrm{M})$ & 72 & & 749 & 694 \\
\hline S. B. (32 M) & 72 & & 624 & 583 \\
\hline \multirow[t]{2}{*}{ D. B. $(35 \mathrm{M})$} & 72 & & 591 & 515 \\
\hline & & Mean & 691 & 631 \\
\hline \multicolumn{5}{|c|}{ H Homozygotes } \\
\hline M. C. $(8$ F) & 72 & & 14 & 12 \\
\hline K. W. $(13 \mathrm{~F})$ & 72 & & 18 & 1 \\
\hline D. R. $(15 \mathrm{~F})$ & 72 & & 73 & 49 \\
\hline & & Mean & 35 & \\
\hline
\end{tabular}

Lymphocytes were isolated from $20 \mathrm{ml}$ of venous blood obtained from each of the indicated subjects, and a single stock flask was prepared as described in Methods. After incubation at $37^{\circ} \mathrm{C}$ in medium A containing $10 \%$ lipoproteindeficient serum for the indicated time, the medium and cells from each flask were divided into five 2-ml aliquots. Each $2 \mathrm{ml}$ aliquot was transferred to a 30-ml flask, after which was added $10 \mu \mathrm{g}$ protein/ml of ${ }^{125} \mathrm{I}-\mathrm{LDL}(150-223 \mathrm{cpm} / \mathrm{ng})$ either in the presence or absence of $250 \mu \mathrm{g}$ protein/ml of unlabeled LDL. After incubation for $6 \mathrm{~h}$ at $37^{\circ} \mathrm{C}$, the medium and cells from each flask were separated by centrifugation, after which the content of ${ }^{125} \mathrm{I}$-LDL-labeled acid-soluble material in the medium was determined as described under Methods. Total and high affinity degradation of ${ }^{125}$ I-LDL were determined as described under Methods. Each value represents the mean of triplicate (- unlabeled LDL) or duplicate (+ unlabeled LDL) incubations. The content of cellular protein in each flask averaged $250 \mu \mathrm{g}$, varying among subjects from 160 to $330 \mu \mathrm{g} /$ flask.

\section{DISCUSSION}

In the present studies normal lymphocytes were found to possess only a small number of high affinity LDL receptors immediately after they were isolated from the blood stream and hence these cells exhibited a low capacity to take up and degrade ${ }^{125}$ I-LDL with high affinity. However, when such cells were incu- bated in vitro in the absence of an exogenous source of cholesterol, they developed an enhanced number of LDL receptors and thus acquired an increased ability to take up and degrade the lipoprotein with high affinity.

The LDL receptors that were expressed on cholesterol-deprived lymphocytes resembled the previously characterized LDL receptors of cholesterol-deprived cultured human fibroblasts $(2-4,14)$ and lymphoid cells (16) in the following ways. First, the LDL receptors of the incubated human lymphocytes showed a marked preference for binding LDL as opposed to HDL or other plasma proteins (such as albumin). Second, the binding of ${ }^{125}$ I-LDL achieved saturation at LDL concentrations below $50 \mu \mathrm{g}$ protein $/ \mathrm{ml}$. Third, the increase in high affinity binding was temporally coupled to an increase in the high affinity processes for the internalization and proteolytic degradation of the lipoprotein. Fourth, the increase in high affinity LDL degradation in circulating lymphocytes was prevented by exposure of the cells to either LDL or a mixture of 25-hydroxycholesterol plus cholesterol, indicating that it was subject to metabolic regulation. Fifth, LDL receptor activity, as reflected by measurement of either the binding or degradation of ${ }^{125} \mathrm{I}-\mathrm{LDL}$, was not expressed in lymphocytes from FH homozygotes.

Two lines of evidence excluded the possibility that the low number of LDL receptors in freshly isolated lymphocytes was a result of damage to the cells during their isolation. First, the isolation procedure did not reduce the ability of the cells to degrade cationized LDL (DMPA-LDL). And second, the appearance of receptor sites could be specifically blocked by inclusion of low levels of LDL in the 72-h incubation mixture. It was also possible, at least in theory, that the low level of receptor activity in the freshly isolated lymphocytes was due to occupancy of the receptor sites by LDL to which the cells had been exposed in the blood stream. However, we have previously shown in both cultured human fibroblasts and lymphoid cells that all receptor-bound LDL is internalized within $7 \mathrm{~min}$ at $37^{\circ} \mathrm{C}$ and that this internalization leads to the regeneration of the original number of unoccupied receptor sites $(3,4,14,16)$. In the present studies the degradation experiments were carried out for $6 \mathrm{~h}$ at $37^{\circ} \mathrm{C}$, an interval that is far in excess of the time required for prebound plasma LDL to be cleared from the receptor sites. This conclusion is supported by the data in Tables III and IV. In the normal cells that had been incubated for $72 \mathrm{~h}$ in the absence of lipoproteins, the rate of high affinity degradation of ${ }^{125} \mathrm{I}$-LDL was $631 \mathrm{ng} \cdot \mathrm{mg}^{-1} \cdot 6$ $\mathrm{h}^{-1}$, which is equal to $1.75 \mathrm{ng} \cdot \mathrm{mg}^{-1} \cdot \mathrm{min}^{-1}$ (Table IV). Under these conditions the surface binding of ${ }^{125} \mathrm{I}-\mathrm{LDL}$ was $14 \mathrm{ng} / \mathrm{mg}$ (Table III). Thus, in the steady- 
state an amount of ${ }^{125}$ I-LDL equal to the amount bound to the receptor was degraded every $14 \div 1.75$ $=8.0 \mathrm{~min}$. This figure is in close agreement with the figure of $6.25 \mathrm{~min}$ for the turnover of receptorbound LDL in fibroblasts (4).

A point worthy of discussion is the difference in sensitivity between the two assays used to measure the function of the LDL receptor in lymphocytes, namely the measurement of high affinity binding at $4^{\circ} \mathrm{C}$ and the measurement of the rate of high affinity degradation at $37^{\circ} \mathrm{C}$. The binding assay is stoichiometric. That is, the number of particles of ${ }^{125} \mathrm{I}-\mathrm{LDL}$ bound to the cells is equal to the number of LDL receptors. On the other hand, the degradation assay is equivalent to a catalytic assay for the LDL receptor. That is, the number of ${ }^{125} \mathrm{I}$ LDL particles degraded is equal to many times the number of receptor molecules since each receptor internalizes many particles of LDL during the usual $6 \mathrm{~h}$ incubation. Because of this amplification effect, the assay for high affinity degradation gives values that are many fold higher than the background. On the other hand, the assay for high affinity surface binding is less discriminative at low receptor levels. Thus, as shown by the data in Table IV, in the freshly isolated lymphocytes obtained from normal subjects the degradation assay was sensitive enough to reveal detectable amounts of high affinity ${ }^{125}$ I-LDL degradation, a finding that implies the presence of small amounts of high affinity ${ }^{125}$ I-LDL binding and uptake. However, as shown by the data in Table III, this amount of receptor activity in nonincubated cells was not sufficiently large to be reliably distinguished from the blank value when ${ }^{125} \mathrm{I}-\mathrm{LDL}$ binding was measured directly at $4^{\circ} \mathrm{C}$.

The current data indicate that at least one type of cell in the human body, the circulating lymphocyte, has the capacity to produce a high affinity LDL receptor that enables the cell to take up and degrade ${ }^{125}$ I-LDL. The data further indicate that this capacity is only partially expressed in the steady state in vivo. Since suppression of LDL receptor activity can be maintained in vitro by a continuous exposure of the lymphocytes to LDL and since in vivo lymphocytes are normally exposed to a high level of LDL in the circulation, it is reasonable to suppose that the suppression of LDL receptor activity in vivo is due to the presence of plasma LDL. By analogy to the situation in cultured human fibroblasts $(1,14)$, it seems likely that the small number of LDL receptors that are normally present on circulating lymphocytes are sufficient to supply all of the cholesterol requirements of these cells so long as they are continuously exposed to LDL. It is only after lymphocytes are deprived of cholesterol that they develop a sterol deficit and hence begin to synthesize high levels of LDL receptors.

The demonstration that the LDL receptor in freshly isolated lymphocytes does in fact function to regulate cellular cholesterol homeostasis as in cultured human fibroblasts and long-term lymphoid cells will require further studies relating LDL receptor activity to the processes of cholesterol synthesis and cholesteryl ester formation in these cells. That such a correlation may indeed exist is suggested by studies of Fogelman et al. $(26,27)$ Higgins et al. (28), and Williams and Avigan (29), who have shown that mixed human leukocytes develop an enhanced rate of cholesterol synthesis when incubated in vitro in the absence of lipoproteins.

\section{ACKNOWLEDGMENTS}

This research was supported by grants from the National Foundation-March of Dimes (6-76-138) and the National Institutes of Health (HL 16024, GM 19258, and 5 MOI-RR00633).

\section{REFERENCES}

1. Brown, M. S., and J. L. Goldstein, 1976. Receptormediated control of cholesterol metabolism. Study of human mutants has disclosed how cells regulate a substance that is both vital and lethal. Science (Wash. D. C.) 191: $150-154$.

2. Brown, M. S., and J. L. Goldstein, 1974. Familial hypercholesterolemia: Defective binding of lipoproteins to cultured fibroblasts associated with impaired regulation of 3-hydroxy-3-methylglutaryl coenzyme A reductase activity. Proc. Natl. Acad. Sci. U. S. A. 71: 788-792.

3. Goldstein, J. L., and M. S. Brown. 1974. Binding and degradation of low density lipoproteins by cultured human fibroblasts: Comparison of cells from a normal subject and from a patient with homozygous familial hypercholesterolemia. J. Biol. Chem. 249: 5153-5162.

4. Goldstein, J. L., S. K. Basu, G. Y. Brunschede, and M. S. Brown. 1976. Release of low density lipoprotein from its cell surface receptor by sulfated glycosaminoglycans. Cell. 7: 85-95.

5. Anderson, R. G. W., J. L. Goldstein, and M. S. Brown. 1976. Localization of low density lipoprotein receptors on the plasma membrane of normal human fibroblasts and their absence in cells from a familial hypercholesterolemia homozygote. Proc. Natl. Acad. Sci. U. S. A. 73: 2564-2568.

6. Brown, M. S., S. E. Dana, and J. L. Goldstein. 1975. Receptor-dependent hydrolysis of cholesteryl esters contained in plasma low density lipoprotein. Proc. Natl. Acad. Sci. U. S. A. 72: 2925-2929.

7. Goldstein, J. L., G. Y. Brunschede, and M. S. Brown. 1975. Inhibition of the proteolytic degradation of low density lipoprotein in human fibroblasts by chloroquine, concanavalin A, and Triton WR 1339. J. Biol. Chem. 250: 7854-7862.

8. Goldstein, J. L., S. E. Dana, J. R. Faust, A. L. Beaudet, and M. S. Brown. 1975. Role of lysosomal acid lipase in the metabolism of plasma low density lipoprotein: Observations in cultured fibroblasts from a patient with cholesteryl ester storage disease. J. Biol. Chem. 250: 8487-8795.

9. Brown, M. S., J. R. Faust, and J. L. Goldstein. 1975. Role of the low density lipoprotein receptor in regulating the content of free and esterified cholesterol in human fibroblasts. J. Clin. Invest. 55: 783-793. 
10. Brown, M. S., and J. L. Goldstein, 1974. Suppression of 3-hydroxy-3-methylglutaryl coenzyme A reductase activity and inhibition of growth of human fibroblasts by 7-ketocholesterol. J. Biol. Chem. 249: 7306-7314.

11. Brown, M. S., S. E. Dana, and J. L. Goldstein. 1974. Regulation of 3-hydroxy-3-methylglutaryl coenzyme A reductase activity in cultured human fibroblasts: Comparison of cells from a normal subject and from a patient with homozygous familial hypercholesterolemia. J. Biol. Chem. 249: 789-796

12. Goldstein, J. L., S. E. Dana, and M. S. Brown. 1974. Esterification of low density lipoprotein cholesterol in human fibroblasts and its absence in homozygous familial hypercholesterolemia. Proc. Natl. Acad. Sci. U. S. A 71: 4288-4292.

13. Brown, M. S., S. E. Dana, and J. L. Goldstein. 1975. Cholesterol ester formation in cultured human fibroblasts: Stimulation by oxygenated sterols. J. Biol. Chem 250: 4025-4027.

14. Brown, M. S., and J. L. Goldstein. 1975. Regulation of the activity of the low density lipoprotein receptor in human fibroblasts. Cell. 6: 307-316.

15. Kayden, H. J., L. Hatam, and N. G. Beratis. 1976. Regulation of 3-hydroxy-3-methylglutaryl coenzyme A reductase activity and the esterification of cholesterol in human long term lymphoid cell lines. Biochemistry. 15: $521-528$.

16. Ho, Y. K., M. S. Brown, H. J. Kayden, and J. L. Goldstein. 1976. Binding, intemalization, and hydrolysis of low density lipoprotein in long-term lymphoid cell lines from a normal subject and a patient with homozygous familial hypercholesterolemia. J. Exp. Med. 144: 444-455.

17. Brown, M. S., and J. L. Goldstein. 1976. Familial hypercholesterolemia: A genetic defect in the low density lipoprotein receptor. N. Engl. J. Med. 294: 1386-1390.

18. Reichl, D., L. A. Simons, N. B. Myant, J. J. Pflug, and G. L. Mills. 1973. The lipids and lipoproteins of human peripheral lymph, with observations on the transpert of cholesterol from plasma and tissues into lymph. Clin. Sci. Mol. Med. 45: 313-329.

19. Reichl, D., A. Postiglione, N. B. Myant, J. J. Pflug, and M. Press. 1975. Observations on the passage of apoproteins from plasma lipoproteins into peripheral lymph in two men. Clin. Sci. Mol. Med. 49: 419-426.

20. Reichl, D., Postiglione, A., and N. B. Mvant. 1976.
Uptake and catabolism of low density lipoprotein by human lymphocytes. Nature (Lond.) 260: 634-635.

21. Brown, M. S., and J. L. Goldstein. 1975. Familial hypercholesterolemia: Genetic, biochemical and pathophysiologic considerations. Adv. Intern. Med. 20: 273296.

22. Basu, S. K., J. L. Goldstein, R. G. W. Anderson, and M. S. Brown. 1976. Degradation of cationized low density lipoprotein and regulation of cholesterol metabolism in homozygous familial hypercholesterolemia fibroblasts. Proc. Natl. Acad. Sci. U. S. A. 73: 3178-3182.

23. Böyum, A. 1968. Isolation of mononuclear cells and granulocytes from human blood. Isolation of mononuclear cells by one centrifugation, and of granulocytes by combining centrifugation and sedimentation at $1 \mathrm{~g}$. Scand. $J$. Clin. Lab. Invest. 97 (Suppl. 21): 77-89.

24. Bierman, E. L., O. Stein, and Y. Stein. 1974. Lipoprotein uptake and metabolism by rat aortic smooth muscle cells in tissue culture. Circ. Res. 35: 136-150.

25. Lowry, O. H., N. J. Rosebrough, A. L. Farr, and R. J Randall. 1951. Protein measurement with the Folin phenol reagent. J. Biol. Chem. 193: 265-275.

26. Fogelman, A. M., J. Edmond, A. Polito, and G. Popjah. 1973. Control of lipid metabolism in human leukocvtes. J. Biol. Chem. 248: 6928-6929.

27. Fogelman, A. M., J. Edmond, J. Seager, and G. Popjak 1975. Abnormal induction of 3-hydroxy-3-methylglutaryl coenzyme A reductase in leukocytes from subjects with heterozygous familial hypercholesterolemia. J. Biol. Chem. 250: 2045-2055.

28. Higgins, M. J. P., D. S. Lecamwasam, and D. J. Galton. 1976. A new type of familial hypercholesterolaemia. Lancet II: $737-740$.

29. Williams, C. D. and Avigan, J. 1972. In vitro effects of serum proteins and lipids on lipid synthesis in human skin fibroblasts and leukocytes grown in culture. Biochim. Biophys. Acta 260: 413-423.

30. Goldstein, J. L., S. E. Dana, G. Y. Brunschede and M. S. Brown, 1975. Genetic heterogeneity in familial hypercholesterolemia: Evidence for two different mutations affecting functions of low density lipoprotein receptor. Proc. Natl. Acad. Sci. U. S. A. 72: 1092-1096.

31. Bilheimer, D. W., J. L. Goldstein, S. M. Grundy, and M. S. Brown, 1975. Reduction in cholesterol and low density lipoprotein synthesis after portacaval shunt surgery in a patient with homozygous familial hypercholesterolemia. J. Clin. Invest. 56: 1420-1430. 